УДК 615.1:37.014.54:378.4:659.4.012:338

DOI https://doi.org/10.11603/2312-0967.2021.4.12704

\title{
АНАЛІЗ ІНСТРУМЕНТІВ ФОРМУВАННЯ БРЕНДУ ОСВІТНЬОЇ ПОСЛУГИ НАЦІОНАЛЬНОГО ФАРМАЦЕВТИЧНОГО УНІВЕРСИТЕТУ
}

\author{
А. В. Волкова, О. Ю. Яковлєва \\ Національний фрармацевтичний університет моз України, Харків \\ o.yakovlieva@nuph.edu.ua
}

ІНФОРМАЦІЯ

Надійшла до редакції / Received: 14.12.2021

Після доопрацювання / Revised: 17.12.2021

Прийнято до друку / Accepted: 20.12.2021

\section{Ключові слова:}

бренд;

освітня послуга;

аналіз;

інструменти;

заклад вищої освіти.
АНОТАЦІЯ

Мета роботи. Проведення аналізу інструментів формування бренду освітньої послуги Національного фрармацевтичного університету за ключовими напрямами обізнаності про заклади вищої освіти (3ВО).

Матеріали і методи. Наукові дані та нормативні документи стосовно інструментів формування бренду освітньої послуги 3ВО, анкети респондентів (здобувачів вищої освіти та потенційні вступники); використано теоретичні (аналіз наукової літератури, узагальнення, класифрікації, аналітичний, порівняльний та логічний) та емпіричний (опису, порівняння) методи, а також методи дослідження бренду: психосемантичні, спрямованих асоціацій, персоніфрікації; побудова карти позиціонування.

Результати й обговорення. В умовах конкуренції у ссрері освіти для ЗВО значущим фрактором існування на ринку $є$ відповідність очікуванням споживачів освітніх послуг, тому на перший план виходять бренди, оскільки споживачів значною мірою привертають емоції, які вони викликають.

За результатами узагальнення даних наукової літератури було визначено напрями для аналізу інструментів фрормування бренду освітньої послуги. Першим етапом аналізу стало дослідження ролі корпоративної символіки у створенні бренду освітньої послуги. Другим етапом - дослідження особливостей впливу веб-сайту НФаУ на створення бренду освітньої послуги. Третій етап - вивчення впливу показників міжнародних та українських рейтингів на формування бренду освітньої послуги НФаУ. Четвертий етап формування карти позиціонування, індивідуалізації та ідентичності бренду освітньої послуги НФаУ.

Проаналізовані інструменти і розроблені карти дали змогу виявити «точки паритету» (асоціації, які не $€$ чимось унікальним, але володіння якими $\epsilon$ необхідним в умовах конкурентної боротьби) і «точки диференціації» (атрибути або переваги бренду освітньої послуги, які споживачі міцно пов'язують з ним, позитивно оцінюють і вважають (вірять), що в інших брендів вони відсутні).

За підсумками проведеного аналізу інструментів формування бренду освітньої послуги НФаУ було відзначено наявність значного потенціалу ЗВО в напрямі формування обізнаності про заклад.

Висновки. У результаті проведеного дослідження зроблено висновок, що позиціонування бренду освітньої послуги дає змогу виявити місце ЗВО серед конкурентів, визначити набір потреб в освітніх послугах і їхнє сприйняття споживачами.

ISSN 2312-0967. Фармацевтичний часопис. 2021. № 4 
Досліджено роль корпоративної символіки у створенні бренду освітньої послуги НФаУ. Визначено роль та можливості отримання інфрормації потенційними вступниками про НФаУ із веб-сайту університету. Проаналізовано місце НФаУ в міжнародних та українських рейтингах й визначено їхній вплив на формування бренду освітньої послуги НФаУ. На основі отриманих результатів побудовано карту позиціонування, індивідуалізації та ідентичності бренду освітньої послуги НФаУ.

Вступ. Насиченість ринку освітніх послуг закладами освіти різних фрорм власності, висока конкуренція між ними, велика кількість освітніх програм і спеціальностей, які заклади пропонують споживачам освітніх послуг, та демограсрічна криза в Україні зумовлюють прагнення закладів вищої освіти (3ВО) приділяти підвищену увагу маркетинговому просуванню освітніх послуг, які надаються закладами.

Аналіз інструментів формування бренду освітньої послуги надає ЗВО можливість визначити власне місце серед конкурентів, набір потреб в освітніх послугах і рівень сприйняття споживачами. Отже, бренд ЗВО доцільно розглядати у трьох площинах: внутрішній потенціал; взаємодія з оточенням; розвиток закладу освіти [1].

В умовах жорсткої конкуренції у сфері освіти для ЗВО значущим фрактором існування на ринку $є$ відповідність очікуванням споживачів освітніх послуг, тому на перший план виходять бренди, оскільки споживачів значною мірою привертають емоції, що породжуються ними.

Питання формування бренду освітньої послуги останнім часом $€$ у центрі уваги багатьох вітчизняних та закордонних вчених та практиків. Актуальними та своєчасними, на нашу думку, є праці таких вчених, як І. Алікперова [2], В. Ванюшкина [3], О. Жегус [4], О. Забарна [5], М. Зацерківна [6], Л. Калашнікова [7], О. Нєчаєва [8], О. Ніфратова [9], С. Семенюк [10], О. Сороки [11] та ін., якими визнано важливість фрормування бренду ЗВО, оскільки він дає можливість підвищити впізнаваність закладу освіти, покращити й зміцнити його престиж тощо. Але низка проблемних питань щодо визначення та аналізу інструментів фрормування бренду освітньої послуги ЗВО є невирішеними та потребують детального опрацювання. За результатами узагальнення даних наукової літератури, визначено напрями для аналізу інструментів формування бренду освітньої послуги.

Мета роботи - проведення аналізу інструментів формування бренду освітньої послуги Національного фрармацевтичного університету (НФаУ) за ключовими напрямами обізнаності про ЗВО.

Матеріали і методи. Наукові дані та нормативні документи стосовно інструментів формування бренду освітньої послуги ЗВО, анкети респондентів (здобувачів вищої освіти НФаУ та потенційних вступників, які брали участь у заходах, які проводив НФаУ; опитування проводили у період з 2017 до 2019 р.).
Достовірність інформації, отриманої в результаті опитувань, забезпечується відповідним обсягом досліджень. Для визначення репрезентативної вибірки респондентів застосовували теорію вибіркового спостереження, яка враховувала коефіцієнт варіації ознаки, рівень довіри та коефіцієнт варіації граничної похибки. За результатами розрахунку, мінімальний обсяг вибірки для здобувачів вищої освіти становить 252, для потенційних вступників - 1151.

Структура вибірки здобувачів вищої освіти характеризується такими даними: розподіл за фрормою навчання: 291 особа, що складає $91 \%$ опитаних, навчаються за очною фрормою, 29 осіб (9 \%) - за заочною формою.

Серед опитаних потенційних вступників: учні 11 класу - 1287 осіб, що складає 83 \%; 10 класу 186 осіб, що складає $12 \%$; здобувачі освіти коледжів - 77 осіб, що складає $5 \%$.

Ступінь узгодженості думок опитаних був розрахований за допомогою коефріцієнта конкордації (W). Як відомо, чим вищий ступінь узгодженості, тим ближче значення W до 1. За результатами розрахунків встановлено, що коефріцієнт конкордації для здобувачів вищої освіти становив 0,81, для опитаних потенційних вступників - 0,84. 3 метою оцінки значущості коефріцієнта конкордації розраховували критерій Пірсона $\chi^{2}$. Розраховане значення критерію Пірсона перевищує табличні дані, що дає змогу з вірогідністю $95 \%$ стверджувати, що узгодженість висновків опитаних, які брали участь у дослідженні, $є$ не випадковою.

Використано теоретичні (аналіз наукової літератури, узагальнення, класифрікації, аналітичний, порівняльний та логічний) та емпіричний (опису, порівняння) методи, а також методи дослідження бренду: психосемантичні, спрямованих асоціацій, персоніфікації; побудова карти позиціонування.

Результати й обговорення. Першим етапом нашої роботи стало дослідження ролі корпоративної символіки у створенні бренду освітньої послуги. Другим етапом - дослідження особливостей впливу вебсайту на створення бренду освітньої послуги. Третій етап - вивчення впливу показників рейтингів на формування бренду освітньої послуги НФаУ. Четвертий етап - формування карти позиціонування, індивідуалізації та ідентичності бренду освітньої послуги НФаУ.

Невід'ємною частиною бренду ЗВО є корпоративний стиль, який доцільно розглядати як частину орга-

ISSN 2312-0967. Pharmaceutical review. 2021. № 4 
Фармацевтичний менеджмент, маркетинг та логістика Pharmaceutical management, marketing and logistics

нізаційної культури, що об'єднує співробітників та споживачів освітніх послуг (здобувачів освіти та потенційних вступників), забезпечуючи відчуття приналежності до ЗВО й ідентифрікацію як єдиного цілого 3 ним. До елементів корпоративного стилю відносять корпоративну символіку (назва, логотип, веб-сайт, слоган, прапор, вивіски, фрірмові кольори та шрифти, бланки, конверти, візитівки тощо), рекламну продукцію (буклети, брендволи, сувенірна продукція) та інші, які доступно й максимально повно розкривають суть діяльності та політики ЗВО, його традиції, культуру, переваги [12].

До засобів індивідуалізації бренду освітніх послуг належать: назва ЗВО, логотип ЗВО, діджитал-носії, корпоративна документація, рекламні матеріали, сувенірна продукція, кольорова палітра, шрифти і типографріка, доменні імена, комерційне позначення, інтер'єр-екстер'єр (рис. 1).

3 метою оцінки засобів індивідуалізації бренду освітніх послуг НФаУ проведено опитування респондентів - здобувачів освіти в НФаУ та потенційних вступників, які брали участь у заходах в НФаУ («Ярмарок вакансій», Конкурс для молодих науковців «Панацея молода»). Респонденти оцінювали засоби індивідуалізації в балах від 1 до 5, де 5 - максимальний бал.

За результатами опитування побудовано карту індивідуалізації бренду освітніх послуг НФаУ (рис. 2).

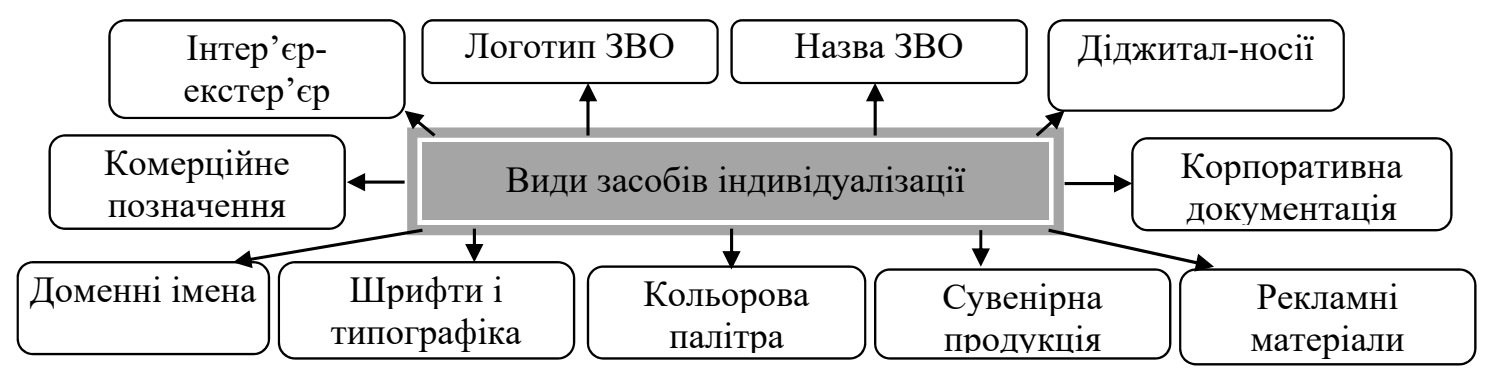

Рис. 1. Засоби індивідуалізації бренду освітніх послуг.

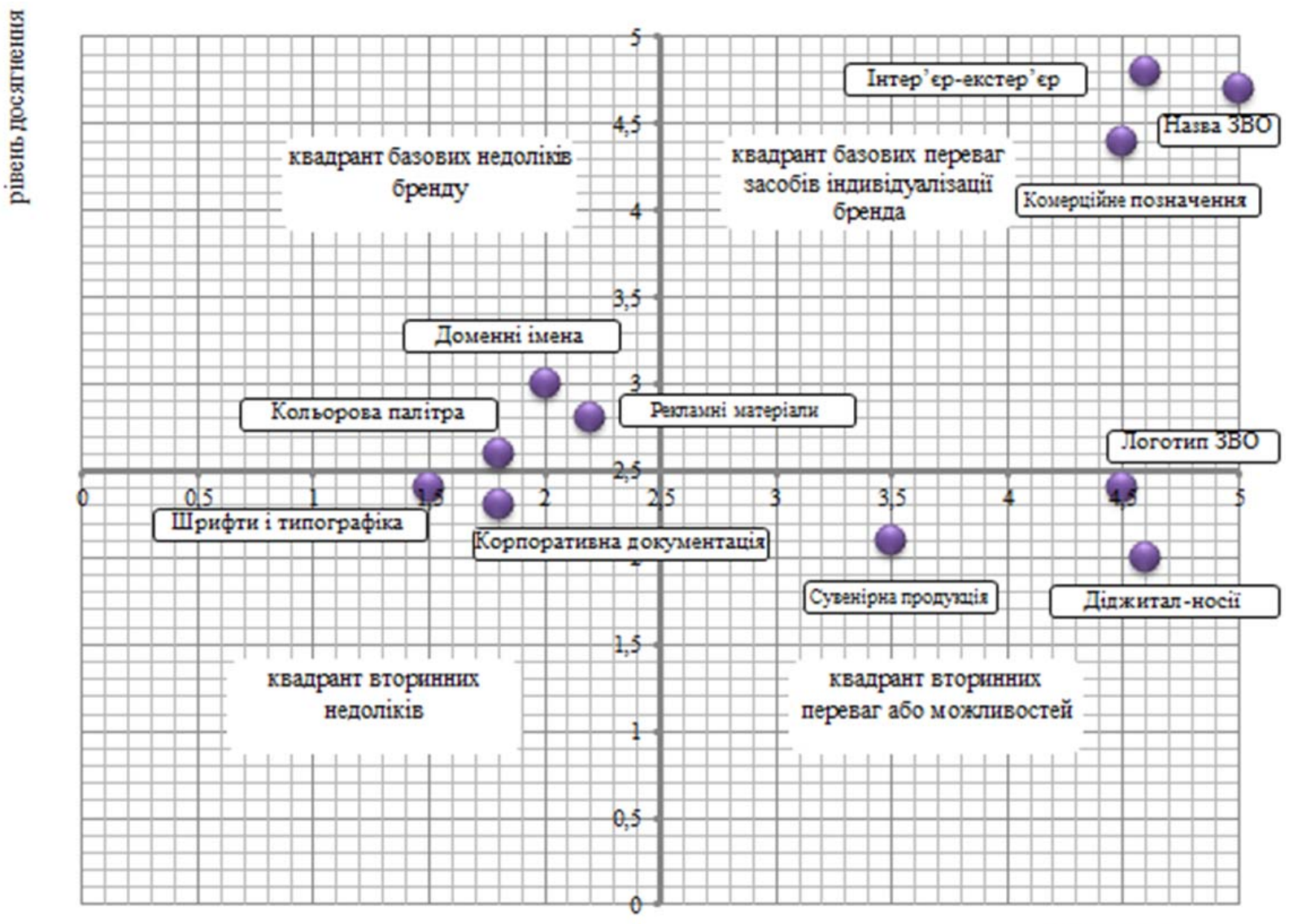

Важливість

Рис. 2. Карта індивідуалізації бренду освітніх послуг НФаУ.

ISSN 2312-0967. Фармацевтичний часопис. 2021. № 4 
Фармацевтичний менеджмент, маркетинг та логістика Pharmaceutical management, marketing and logistics

Як видно з наведеної карти, 3 характеристики з 10 знаходяться в квадранті базових переваг - назва 3ВО, комерційне позначення, інтер'єр-екстер'єр. Відповідно для цих атрибутів необхідною маркетинговою стратегією є підтримка рівня важливості. До правого нижнього квадранту також належать 3 атрибути - логотип 3ВО, сувенірна продукція та діджитал-носії. Важливість їх не настільки висока, на думку споживачів, як базових. Можлива маркетингова стратегія - підвищення важливості атрибутів або підтримка, якщо базові атрибути конкурентоспроможні. До лівого верхнього квадранту належать атрибути 3 невисокою важливістю та високим рівнем досягнення - кольорова палітра, доменні імена та рекламні матеріали. Атрибути, які входять до нижнього лівого квадранту, є недоліками бренду і потребують ретельного доопрацювання.

Отже, проведення аналізу сприйняття зазначених атрибутів здобувачами вищої освіти та потенційними вступниками допомагають ЗВО створити власний унікальний стиль, який відрізняє його від інших закладів, що виступають конкурентами на ринку освітніх послуг.

Про затребуваність освітніх послуг, які надає НФаУ, свідчить, зокрема, середній бал зовнішнього незалежного оцінювання вступників (табл. 1).
Сьогодні, як ніколи, виникає необхідність упровадження та постійного вдосконалення інформаційних технологій, що є ефективними засобами маркетингової політики, підвищення конкурентоспроможності ЗВО, просування освітніх послуг, фрормування позитивного іміджу та стратегії брендингу університету.

Результати проведеного опитування здобувачів вищої освіти і потенційних вступників щодо пріоритетності джерел інфрормації про НФаУ представлено в таблиці 2.

Таким чином, можна стверджувати, що веб-сайт ЗВО є його візитівкою для цільових аудиторій - вступників та їхніх батьків, здобувачів вищої освіти, роботодавців, органів влади, 3MI, партнерів, громадськості.

Основними розділами веб-сайту є «Наш університет», «Вступнику», «Студенту», «Наука», «Міжнародна діяльність».

Важливим моментом оцінювання сайту є його навігація, яка полегшує користування ним (подорож сайтом) та спрямування відвідувача на необхідні сторінки.

Для визначення відомості веб-сайту НФаУ, а відповідно, і його іміджу, проведено аналіз статистики його відвідувань у період 2017-2020рр. (табл. 3).

\section{Таблиця 1}

Середній бал зовнішнього незалежного оцінювання вступників (спеціальність 226 Фармація, промислова фрармація, освітній ступінь «магістр»)

\begin{tabular}{|c|c|c|c|c|}
\hline Показник & 2017 & 2018 & 2019 & 2020 \\
\hline $\begin{array}{l}\text { Кількість ЗВО, які здійснюють підготовку фрахівців за } \\
\text { спеціальністю } 226 \text { Фармація, промислова фрармація }\end{array}$ & 12 & 14 & 23 & 23 \\
\hline $\begin{array}{l}\text { Місце НФаУ серед ЗВО } \\
\text { за середнім балом ЗНО (бюджет) }\end{array}$ & 3 & 2 & 1 & 4 \\
\hline Середній бал вступників НФаУ (бюджет) & 191 & 194 & 191 & 169 \\
\hline Середній бал вступників НФаУ (контракт) & 156 & 151 & 151 & 155 \\
\hline
\end{tabular}

Таблиця 2

Результати опитування респондентів щодо пріоритетності джерел інформації про НФаУ

\begin{tabular}{|l|c|c|}
\hline \multicolumn{1}{|c|}{ Джерело інсрормації } & Місце & \% респондентів \\
\hline Ооріційний веб-сайт університету & 1 & 57 \\
\hline $\begin{array}{l}\text { Освітні інтернет-портали та івенти, які організовує 3ВО для } \\
\text { потенційних вступників }\end{array}$ & 2 & 39 \\
\hline Батьки, друзі та знайомі & 3 & 24 \\
\hline
\end{tabular}

Таблиця 3

Статистика відвідувань веб-сайту НФаУ

\begin{tabular}{|c|c|c|c|c|}
\hline Рік & Унікальні відвідувачі & Кількість відвідувань & Кількість сторінок & Хіти \\
\hline 2017 & 433682 & 737782 & 7276375 & 51802977 \\
\hline 2018 & 399136 & 680802 & 7763137 & 49250830 \\
\hline 2019 & 471856 & 822035 & 8833803 & 50896976 \\
\hline 2020 & 452921 & 735282 & 8205325 & 47854458 \\
\hline
\end{tabular}

ISSN 2312-0967. Pharmaceutical review. 2021. № 4 
Фармацевтичний менеджмент, маркетинг та логістика Pharmaceutical management, marketing and logistics

На підставі аналізу наведених даних, можна зробити висновок про значні коливання досліджуваних критеріїв у 2019-2020 рр., що пояснюється невизначеністю молоді щодо майбутньої професії.

Загальновідомо, що користувачі мережі Internet цінують достовірність та повноту інфрормації, яку вони отримують. У зв'язку з цим інфрормаційне наповнення веб-сайту є суттєвою характеристикою у формуванні позитивного іміджу ЗВО і сприяє довірі цільової аудиторії до нього.

Імідж освітньої послуги визначається також відповідними позиціями в різноманітних рейтингах, які $€$ важливим інструментом залучення вступників, тому що чим вище в рейтингу знаходиться ЗВО, тим привабливішим він виглядає для вступника (потенційного споживача освітніх послуг) та роботодавця (кінцевого споживача освітніх послуг).

На наступному етапі проаналізовано рейтингові показники НФаУ за 5 років в основних рейтингах, де представлені 3ВО України (табл. 4).

Так, у рейтингу Webometrics, який оцінює глобальну діяльність ЗВО з урахуванням її результатів, а також їхню актуальність та вплив, у 2015 р. НФаУ посідав 72 місце серед 295 ЗВО України. У 2020 р. НФаУ покращив свої позиції: серед 317 ЗВО України він посів 50 місце, що позитивно впливає на імідж закладу і його привабливість для вступників [13].
Згідно з рейтингом ЗВО за показниками Scopus, який засновується на якості наукових публікацій, НФаУ посідав у 2015 р. 43 місце серед 122 ЗВО України. Суттєве покращення показників спостерігалося у 2018 р., коли зі 161 ЗВО України НФаУ посів 31, але у 2020 р. серед 177 ЗВО він посів 35 місце [13].

На підставі дослідження рейтингів Webometrics та Scopus, можна зробити висновок, що для формування високого іміджу НФаУ необхідно посилити роботу 3 поширення наукових знань шляхом збільшення кількості наукових публікацій у виданнях, які індексуються наукометричними базами.

Також проаналізовано рейтинг ТОП 200 Україна. Відповідно до рейтингу, НФаУ у 2015 р. посідав 32 місце. За підсумками 2020 р. рейтингові позиції значно покращилися - НФаУ посів 15 місце [13]. Так, успішною діяльністю НФаУ є кадрова політика, фрінансова та господарська діяльність. Достатньо успішними є навчально-методична та виховна робота; наукова діяльність; міжнародне, державне та галузеве визнання. Потребують покращення такі показники діяльності: кількість отриманих патентів на винахід та корисні моделі; кількість осіб, яким присвоєно звання заслужених діячів та працівників, присуджено державні премії України, обраних до державних академій; участь у програмах двостороннього та багатостороннього міжнародного обміну науково-педагогічних працівників і здобувачів вищої освіти тощо.

\section{Таблиця 4}

Рейтинг НФаУ за рейтингом Webometrics, Scopus, ТОП 200 Україна

\begin{tabular}{|c|c|c|c|c|c|}
\hline \multirow{2}{*}{$\begin{array}{l}\text { Джерело } \\
\text { даних }\end{array}$} & \multirow{2}{*}{ Рік } & \multirow{2}{*}{$\begin{array}{c}\text { Кількість досліджуваних } \\
\text { ЗВО }\end{array}$} & \multicolumn{3}{|c|}{ Ранг НФаУ серед } \\
\hline & & & ЗВО України & ЗВО Харкова & медичних ЗВО \\
\hline \multirow[t]{6}{*}{ Webometrics } & 2015 & 295 & 72 & 7 & 6 \\
\hline & 2016 & 344 & $60(+21)$ & $8(-1)$ & 6 \\
\hline & 2017 & 330 & $50(+10)$ & $6(+2)$ & 6 \\
\hline & 2018 & 327 & $51(-1)$ & $7(-1)$ & $5(+1)$ \\
\hline & 2019 & 320 & $22(+29)$ & $4(+3)$ & $4(+1)$ \\
\hline & 2020 & 317 & $50(-28)$ & $8(-4)$ & $5(-1)$ \\
\hline \multirow[t]{6}{*}{ Scopus } & 2015 & 122 & 43 & 6 & 7 \\
\hline & 2016 & 128 & $47(-4)$ & 6 & 7 \\
\hline & 2017 & 136 & $52(-5)$ & 6 & $10(-3)$ \\
\hline & 2018 & 161 & $31(+21)$ & 6 & $6(+4)$ \\
\hline & 2019 & 166 & $33(-2)$ & 6 & $8(-2)$ \\
\hline & 2020 & 177 & $35(-2)$ & 6 & 8 \\
\hline \multirow{6}{*}{$\begin{array}{l}\text { ТОП } 200 \\
\text { Україна }\end{array}$} & 2015 & 200 & 32 & 6 & 4 \\
\hline & 2016 & 200 & $22(+10)$ & 6 & $2(+2)$ \\
\hline & 2017 & 200 & $21(+1)$ & $5(+1)$ & 2 \\
\hline & 2018 & 200 & $20(+1)$ & 5 & 2 \\
\hline & 2019 & 200 & $26(-6)$ & $7(-2)$ & $3(-1)$ \\
\hline & 2020 & 200 & $15(+11)$ & $4(+3)$ & $1(+2)$ \\
\hline
\end{tabular}

ISSN 2312-0967. Фармацевтичний часопис. 2021. № 4 
Фармацевтичний менеджмент, маркетинг та логістика Pharmaceutical management, marketing and logistics

Позиціонування завжди здійснюється з урахуванням конкретної цільової групи споживачів, для якої створюються і пропонуються переваги й унікальності, та дає змогу сорормувати більш ефективні комбінації інструментів просування бренду освітньої послуги. Отже, з метою виявлення споживчих переваг і сприйняття того чи іншого бренду освітніх послуг доцільно використовувати такий метод, як побудова карти позиціонування (сприйняття). Відповідно, на завершальному етапі дослідження, за отриманими результатами, побудовано карту позиціонування, індивідуалізації та ідентичності бренду освітньої послуги НФаУ.

3 метою побудови карти позиціонування бренду освітніх послуг проведено визначення показників про уявлення та сприйняття рівня та якості їх надання, які пропонувалось оцінити під час опитування здобувачам вищої освіти НФаУ і потенційним вступникам, які відвідували НФаУ під час проведення «Ярмарків вакансій» та Всеукраїнського конкурсу на присудження нагороди для обдарованої молоді та юнацтва «Панацея молода». Залучені до опитування респонденти ранжували запропоновані показники за 5-бальною системою, де 1 - низький рівень, 5 - найвищий рівень.
Показники, запропоновані респондентам:

1) престиж 3ВО;

2) якість освітніх послуг;

3) різноманіття спеціальностей, варіативність освітніх послуг;

4) вартість навчання;

5) затребуваність випускників на ринку праці;

6) профресійність НПП;

7) історія університету;

8) надійність.

Узагальнені результати опитування щодо позицій НФаУ представлено на рисунку 3.

Здобувачі вищої освіти високо сприймають престиж університету (4,8 бала), різноманітність спеціальностей НФаУ (4,7 бала) та професійність НПП (4,6 бала). Ці характеристики вони оцінили вище, ніж потенційні вступники, що пояснюється можливістю здобувачів освіти оцінити якість викладання дисциплін, креативність навчання та застосування сучасних методів викладачами університету. Особливістю цих характеристик $є$ те, що вони передаються «з вуст в уста» та можуть бути висвітлені в рекламних проспектах і сприяти підвищенню іміджу ЗВО серед потенційних вступників. Майже максимально (4,8 бала) здобувачі осві-

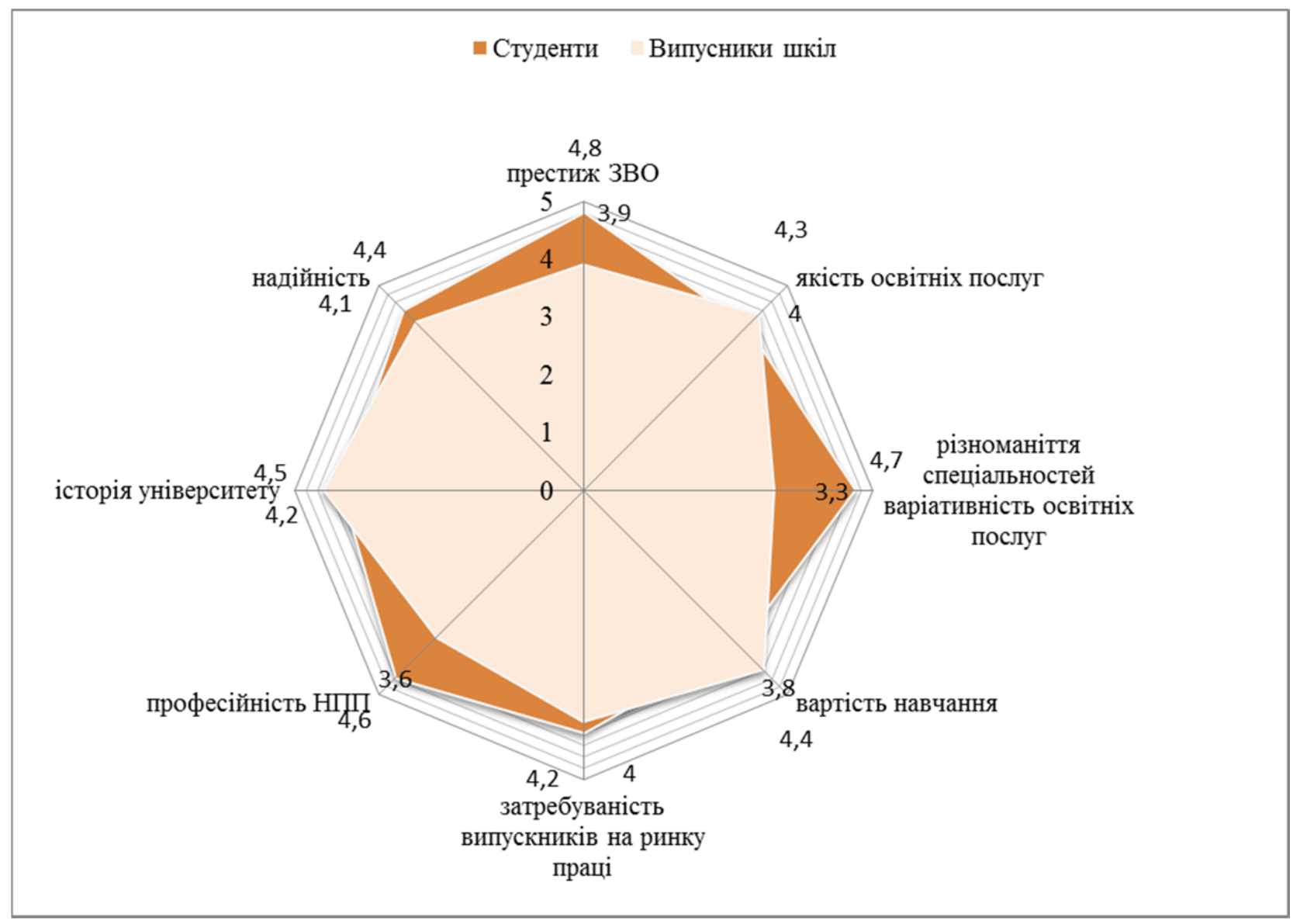

Рис. 3. Радар показників позиціонування бренду освітніх послуг НФаУ споживачами.

ISSN 2312-0967. Pharmaceutical review. 2021. № 4 
Фармацевтичний менеджмент, маркетинг та логістика Pharmaceutical management, marketing and logistics

ти оцінили престиж НФаУ. Престиж закладу - характеристика, яка сприймається емоційно, тому її складно передати через рекламу, але цілком можна передати «з вуст в уста». Також здобувачі освіти вище, ніж потенційні вступники, оцінили надійність університету (4,4 бала) та затребуваність випускників на ринку праці (4,2 бала).

Результати оцінки респондентів бренду освітніх послуг НФаУ покладено у створення карти позиціонування, яка складається 3 дев'яти квадрантів із диференціацією за показниками позиціонування за рівнями: низький - 0-2, середній $-2-4$, високий - 4-5 (рис. 4).

Показники позиціонування розподілені таким чином: 1 - престиж 3ВО (для випускників шкіл: важливість показника - 3,6; диференціація - 4,1; для студентів: 4,7 і 4,15 відповідно), 2 - якість освітніх послуг (для випускників шкіл: 4,36 і 4,55 відповідно; для студентів: 3,97 і 4,55 відповідно), 3 - різноманіття спеціальностей, варіативність освітніх послуг (для випускників шкіл: 3,0 і 3,99 відповідно; для студентів: 4,67 і 3,97 відповідно), 4 - вартість навчання (для випускників шкіл: 4,47 і 4,66 відповідно; для студентів: 3,3 і 4,6 відповідно), 5 - затребуваність випускників на ринку праці (для випускників шкіл: 4,0 і 3,99 відповідно; для студентів: 4,2 і 4,22 відповідно), 6 - професійність НПП (для випускників шкіл: 3,0 і 4,22 відповідно; для студентів: 4,57 і 4,22 відповідно), 7 - історія університету (для випускників шкіл: 4,58 і 3,5 відповідно; для студентів: 4,2 і 4,22 відповідно), 8 надійність (для випускників шкіл: 4,4 і 4,8 відповідно; для студентів: 4,0 і 4,8 відповідно).

На підставі проведених досліджень визначено, що ідентичність бренду НФаУ визначається такими характеристиками:
1. Цільова аудиторія: орієнтація на споживачів освітніх послуг, які бажають отримати якісну освіту в престижному закладі.

2. Переваги бренду: інноваційність, креативність і надійність закладу зі славетною історією, висока якість освіти.

3. Позиціонування: міжнародно визнаний освітній бренд $з$ традиціями, за оцінками споживачів та незалежних рейтингів.

4. Сприйняття бренду (асоціації, що виникають у споживача з приводу бренду): якісна освіта та надійне працевлаштування.

5. Відмінності від конкурентів: глибокі історичні корені фрармацевтичної освіти.

6. Індивідуальність: профресіоналізм.

7. Сутність бренду: висока якість фрармацевтичної освіти, яка підтверджується зацікавленістю роботодавців у випускниках НФаУ [14].

Отже, проаналізовані інструменти і розроблені карти дають змогу виявити «точки паритету» (асоціації, які не є чимось унікальним, але володіння якими $\epsilon$ необхідним в умовах конкурентної боротьби) і «точки дисеренціації» (атрибути або переваги бренду освітньої послуги, які споживачі міцно пов'язують 3 ним, позитивно оцінюють і вважають (вірять), що у інших брендів вони відсутні). Із маркетингової точки зору, поліпшення характеристик індивідуалізації освітніх послуг може стати резервною перевагою, особливо у тому випадку, якщо це є спільний з конкурентами недолік.

Таким чином, підбиваючи підсумки проведеного аналізу інструментів фрормування бренду освітньої послуги НФаУ, можна відзначити наявність значного потенціалу ЗВО у напрямі фрормування обізнаності про заклад.

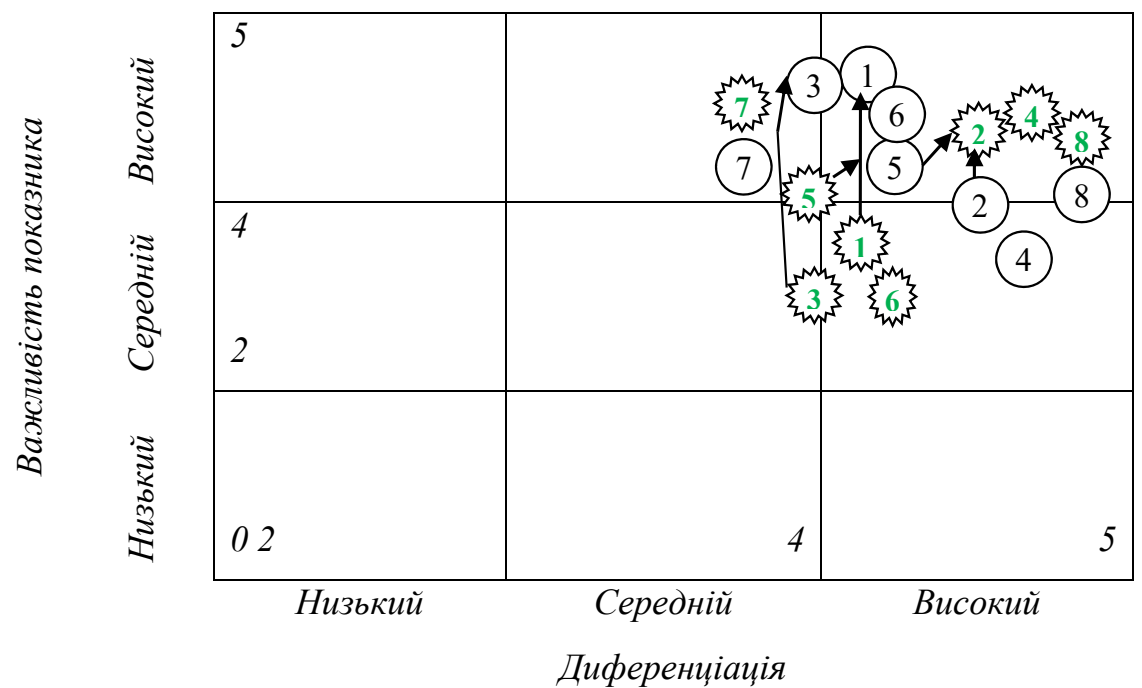

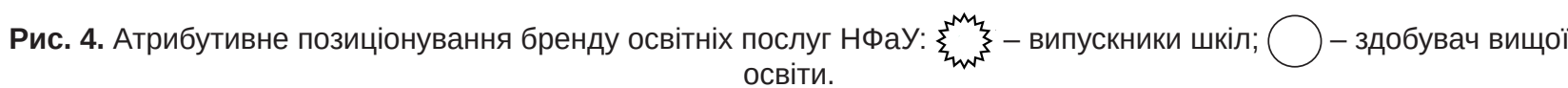

ISSN 2312-0967. Фармацевтичний часопис. 2021. № 4 
Висновки. У результаті проведеного дослідження встановлено, що позиціонування бренду освітньої послуги дає змогу виявити місце ЗВО серед конкурентів, визначити набір потреб в освітніх послугах і їхнє сприйняття споживачами.

Досліджено роль корпоративної символіки у створенні бренду освітньої послуги НФаУ. Зокрема, за результатами її оцінки респондентами побудовано карту індивідуалізації бренду освітніх послуг НФаУ. Відповідно до квадранту, в який входять засоби індивідуалізації бренду освітніх послуг, ЗВО розробляє відповідну маркетингову стратегію.

Визначено роль та можливості отримання інформації вступниками про НФаУ із сайту університету, який, за результатами проведеного опитування здобувачів вищої освіти НФаУ і потенційних вступників, посідає перше місце серед джерел отримання інформації про НФаУ.

Проаналізовано місце НФаУ в міжнародних та українських рейтингах. Визначено вплив рейтингів на формування бренду освітньої послуги НФаУ. Встановлено, що успішною діяльністю НФаУ є кадрова політика, навчально-методична та виховна робота, наукова діяльність, міжнародне, державне, галузеве визнання.
Побудовано карту позиціонування бренду освітніх послуг ЗВО споживачами. Сформовано показники про уявлення та сприйняття рівня й якості надання освітніх послуг, а саме: престиж ЗВО; якість освітніх послуг; різноманітність спеціальностей, варіативність освітніх послуг; вартість навчання; затребуваність випускників на ринку праці; професійність НПП; історія університету; надійність. Встановлено, що для випускників шкіл відносно НФаУ важливими є якість освітніх послуг, вартість навчання та надійність; для здобувачів вищої освіти - престиж 3ВО, затребуваність випускників на ринку праці та профресійність НПП. Визначено характеристики ідентичності бренду освітньої послуги НФаУ: цільова аудиторія, переваги бренду, позиціонування, сприйняття бренду, відмінності від конкурентів, індивідуальність, суть бренду.

Визначено, що запропоновані інструменти і розроблені карти дають змогу виявити «точки паритету» і «точки диференціації» та розробити відповідну маркетингову стратегію ЗВО.

Конфрлікт інтересів: відсутній.

Conflicts of interest: authors have no conflict of interest to declare.

\section{ANALYSIS OF BRAND FORMING TOOLS OF EDUCATIONAL SERVICES AT THE NATIONAL UNIVERSITY OF PHARMACY}

\section{A. V. Volkova, O. Yu. Yakovleva}

National University of Pharmacy, Kharkiv

o.yakovlieva@nuph.edu.ua

The aim of the work. To analyze the brand forming tools of educational services at the National University of Pharmacy in the key areas of awareness about the university.

Materials and Methods. Scientific data and normative documents on the brand forming tools of university educational services, questionnaires of respondents (applicants for higher education and school graduates); theoretical (analysis of scientific literature, generalization, classification, analytical, comparative and logical) and empirical (description, comparison) methods have been used, methods of brand research: psych semantic, directed associations, personification; construction of positioning map.

Results and Discussion. In a competitive environment in the educational field, a significant factor for a university in its existence on the market is compliance with the consumers' expectations of educational services, therefore, brands come to the foreground, since consumers are largely attracted by the emotions they generate.

Based on the results of summarizing the scientific literature data, the directions of the brand forming tools analysis of educational services have been determined. The first stage of the analysis has been the study of the corporate symbols role in creating a brand of educational services. The second stage - to study the features of the influence of the NUPh website on the creation of the educational services brand. The third stage - to study of the influence of the rating indicators on the brand formation of the NUPh educational service. The fourth stage - to form a positioning map, individualization and brand identity of the NUPh educational service.

The analyzed tools and the developed maps have made it possible to identify "points of parity" (associations that are not unique, but which must be possessed in a competitive environment) and "points of differentiation" (attributes or advantages of an educational service brand that consumers firmly associate with it, positively evaluate and believe that other brands do not have them). Based on the analysis of the brand forming tools of the NUPh educational service, it has been noted that there is a significant potential of the University in the direction of awareness of it.

Conclusions. As a result of the study, it has been concluded that the positioning of the educational services brand makes it possible to identify the place of the University among competitors, to determine the set of needs for educational services and their perception by consumers.

ISSN 2312-0967. Pharmaceutical review. 2021. № 4 
Фармацевтичний менеджмент, маркетинг та логістика

Pharmaceutical management, marketing and logistics

The role of corporate symbols in the creation of the NUPh educational services brand has been investigated. The role and the possibility of obtaining information by applicants about the NUPh from the University's website have been determined. The place of the NUPh in the ratings has been analyzed and their influence on the brand formation of the NUPh educational services has been determined. A map of positioning, individualization and brand identity of the NUPh educational service has been built.

Key words: brand; educational service; analysis; tools; higher educational institution.

\section{Список бібліографрічних посилань}

1. Котвіцька А. А., Яковлєва О. Ю. Дослідження особливостей створення бренду закладу вищої освіти. Вісник фрармації. 2021. № 2 (102). DOI: https://doi.org/10.24959/nphj.21.60 (дата звернення: 24.12.2021).

2. Аликперов И. М., Жадько Е. А., Тимохина Г. с. Модель управления брендом образовательной организации. Экономика и предпринимательство. 2016. № 11. С. 474-477.

3. ВанюшкинаВ.В.Брендвысшегопрофессионального учреждения: особенности формирования и продвижения : автореф. дисс. ... канд. экон. наук. Ростов-на-Д., 2011. 24 с.

4. Жегус О. В., Михайлова М. В., Чміль Г. Л. Особливості формування бренду закладу вищої освіти. Вісник Хмельницького національного університету. Економічні науки. 2019. № 5. С. 111-114.

5. Забарна Е. М., Соловьева Е. Ю. Система та критерії маркетингового аналізу сайтів вищих навчальних закладів. Ефрективна економіка. 2013. № 1. URL: http://www.economy.nayka.com.ua/?op=1\&z=1748 (дата звернення: 24.12.2021).

6. Зацерківна M. O. PR-технології у формуванні іміджу закладів вищої освіти сфрери культури : дис. ... канд. наук із соціальних комунікацій за спец. 27.00.06 прикладні соціально-комунікаційні технології. Київ, 2019. 244 c.

7. Калашнікова Л. В. Інтернет-сайти вищих навчальних закладів як інноваційні канали комунікації в умовах фрормування інфрормаційного суспільства в Україні : автореср. дис. ... канд. соціол. наук : 22.00.04. Харків, 2005. 20 c.

\section{References}

1. Kotvitska AA, Yakovlieva OYu. [Research of features of creation of a brand of an institution of higher education]. Visn farm. 2021;2(102). DOI: https://doi.org/10.24959/ nphj.21.60. Ukrainian.

2. Alikperov IM, Zhad'ko EA, Timokhina GS. [Brand management model of an educational organization]. Ekonomika i predprinimatelstvo. 2016;11: 474-7. Russian.

3. Vaniushkina VV. Brend vysshego professionalnogo uchrezhdeniia: osobennosti formirovaniia i prodvizheniia [Brand of a Higher Professional Institution: Features of Formation and Promotion] [dissertation abstract]. Rostov-na-Donu; 2011. 24 p. Russian.

4. Zhehus OV, Mykhailova MV, Chmil HL. [Features of higher education institutions brand formation]. Visnyk
8. Нечаева Е. С., Туркина В. А. Брендинг в системе высшего образования. Известия Тульского государственного университета. Экономические и юридические науки. 2013. № 3 (1). С. 141-149.

9. Ніфратова О. М. Брендинг українських ВНЗ як системоутворюючий чинник підприємницької парадигми вищої освіти. Вісник Київського національного університету технологій та дизайну. Сер. : Економічні науки. Спецвип. : Ефективність організаційно-економічного механізму інноваційного розвитку вищої освіти : матеріали VII Міжнар. наук.-практ. конфр., м. Київ, 6 жовт. 2017 р. Київ, 2017. С. 312-321.

10. Семенюк С. Брендинг вищого навчального закладу. Галицький економічний вісник. 2013. №3 (42). C. 133-138.

11. Сорока О. В., Кривцова М. С. Бренд закладу вищої освіти - основа конкурентоспроможності на ринку освітніх послуг. Науковий вісник Ужгородського національного університету. Серія: Міжнародні економічні відносини та світове господарство. 2018. Вип. 19, ч. 3. С. 65-70.

12. Парсяк В. Н., Драгомірова І. Корпоративна культура вищих навчальних закладів: сутність і складові. Актуальні проблеми економіки. 2009. № 2. С. 97104.

13. Ranking Web of Universities. URL: http://www.webometrics.info/en_(Date of access: 24.12.2021).

14. Аналіз сучасних вимог роботодавців щодо функціональних обов'язків і компетентностей фрармацевтичного персоналу / А. А. Котвіцька [та ін.]. Запорізький медичний журнал. 2020. Т. 22, № 6 (123). C. 847 - 857.

Khmelnytskoho natsionalnoho universytetu. Ekonomichni nauky. 2019;5: 111-4. Ukrainian.

5. Zabarna EM, Soloveva EYu. [System and criteria of marketing analysis of sites of higher educational institutions]. Efektyvna ekonomika. 2013;1. Available from: http://www.economy.nayka.com.ua/?op=1\&z=1748. Ukrainian.

6. Zatserkivna MO. PR-technologies in the formation of the image of institutions of higher education in the field of culture. Thesis. Kyiv; 2019. Ukrainian.

7. Kalashnikova LV. Internet sites of higher educational institutions as innovative channels of communication in the conditions of formation of information society in Ukraine. Thesis. Kharkiv; 2005. Ukrainian.

ISSN 2312-0967. Фармацевтичний часопис. 2021. № 4 
Фармацевтичний менеджмент, маркетинг та логістика Pharmaceutical management, marketing and logistics

8. Nechaeva ES, Turkina VA. Branding in the system of higher education. Izvestiia Tulskogo gosudarstvennogo universiteta. Ekonomicheskie i iuridicheskie nauki. 2013;3(1): 141-9. Russian.

9. Nifatova OM. [The branding of the Ukrainian HEl as a systematic official of the educational paradigm of high education]. Visnyk Kyivskoho natsionalnoho universytetu tekhnolohii ta dyzainu. Ser. Ekonomichni nauky. Spetsvypusk: Efektyvnist orhanizatsiino-ekonomichnoho mekhanizmu innovatsiinoho rozvytku vyshchoi osvity : materialy VII Mizhnar. nauk.-prakt. konf., m. Kyiv, 6 zhovt. 2017 r. Kyiv, 2017. S. 312-321. Ukrainian.

10. Semeniuk S. [Branding of the higher educational establishment]. Halytskyi ekonomichnyi visnyk. 2013;3(42): 133-8. Ukrainian.

11. Soroka AV, Kryvtsova MS. [Brand of the higher edu- cation - the basis of competitiveness on educational services market]. Naukovyi visnyk Uzhhorodskoho natsionalnoho universytetu. Seriia: Mizhnarodni ekonomichni vidnosyny ta svitove hospodarstvo. 2018;19(3): 65-70. Ukrainian.

12. Parsiak VN, Drahomirova I. [Corporate culture of higher educational institutions: essence and components]. Aktualni problemy ekonomiky. 2009;2: 97-104. Ukrainian.

13. Ranking Web of Universities [Internet]. Available from: http://www.webometrics.info/en.

14. Kotvitska AA, Bratishko YuS, Volkova AV, Tarasenko DYu, Posylkina OV, Olkhovska AB. Analysis of modern employers' requirements to responsibilities and competencies of pharmaceutical staff. Zaporozhye medical journal 2020;22(6): 847-57. Ukrainian.

\section{Відомості про авторів}

Волкова А. В. - канд. фрармац. наук, доцент, кафедра соціальної фрармації, Національний фрармацевтичний університет, Харків, Україна. E-mail: volkova.nfau@gmail.com, ORCID: http://orcid.org/0000-0003-2718-5407

Яковлєва О. Ю. - помічник ректора, Національний фрармацевтичний університет, Харків, Україна. Е-таіl: o.yakovlieva@nuph.edu.ua, ORCID: 0000-0002-7211-212X

\section{Information about the authors}

Volkova A. V. - PhD (Pharmacy), Associated Professor, Department of Social Pharmacy, National University of Pharmacy, Kharkiv, Ukraine. ORCID: E-mail: volkova.nfau@gmail.com, ORCID: http://orcid.org/0000-0003-2718-5407

Yakovlieva O. Yu. - rector's assistant, National University of Pharmacy, Kharkiv, Ukraine. E-mail: o.yakovlieva@nuph.edu. ua, ORCID: 0000-0002-7211-212X 